\title{
The challenge of describing the epidemiology of HTLV in the Amazon region of Brazil
}

\author{
Ricardo Ishak*, Marluísa de Oliveira Guimarães Ishak and Antonio Carlos R. Vallinoto
}

\begin{abstract}
HTLV-1 was the first described human retrovirus and was soon found to be associated with severe clinical diseases, including a devastating lymphoma/leukemia and other inflammatory diseases. Although HTLV-2 is not usually pathogenic, it is widely distributed among native Indian populations in Brazil, particularly in the Amazon region of the country. Presently, HTLV spreads mainly by the sexual route and from mother to child, and virus persistence is an active biological factor aiding its transmission. Recently, the use of illicit drugs has been shown to be an additional risk factor, showing the influence of new habits on the epidemiology of HTLV in the region. Despite the detection of the virus in several different populations in the Amazon region of Brazil for almost 30 years, the exact prevalence of HTLV-1/2 is not well defined. The original biases in sampling and the selection of epidemiologically unsuitable populations were commonly repeated in most prevalence studies, generating unreliable and conflicting figures that do not represent the actual prevalence of HTLV. The improvements in clinical and laboratory facilities have resulted in the description of several clinical manifestations that were previously unknown in the region. The extent of the spread of the virus must be defined in this region, which is the largest geographical area of the country. As prophylaxis advances toward the use of vaccines against HTLV-1, it is important to determine who is at risk of being infected and developing a disease to successfully implement preventive measures, particularly as proposals are made to eradicate the virus among humans.
\end{abstract}

Keywords: HTLV-1/2, Prevalence, Epidemiology, Amazon region, Brazil

\section{Background}

Human T cell lymphotropic viruses 1 and 2 (HTLV-1 and HTLV-2) are medium-sized virus particles (80-120 nm) belonging to the family Retroviridae, genus Deltaretrovirus [1]. Presently, there are six molecular subtypes (namely, a, b, c, d, e and f) of HTLV-1 [2-4] and four (a, b, c and d) of HTLV-2 [5-8]. Two other types, HTLV-3 and HTLV-4, have been described [9] as examples of cross-species transmission in a geographically isolated forest area in Cameroon, but so far, neither have been detected elsewhere or have spread further $[10,11]$.

\footnotetext{
*Correspondence: rishak@ufpa.br
}

Laboratório de Virologia, Instituto de Ciências Biológicas, Universidade

Federal do Pará, Rua Augusto Corrêa no.1, Belém, Pará 66075-110, Brazil
Retroviruses share similar biological and replicative properties, including the evolutionary aspect of viral and cell nucleic acid integration, viral persistence, viral latency and vertical transmission to the offspring. HTLV integrates the transcribed RNA as a DNA provirus into the cell nucleic acid [12-16], and this simple evolutionary procedure leads to the persistence of the virus and its maintenance in nature and has serious implications for the different clinical and epidemiological outcomes of the infection and diseases associated with the virus. The wide array of clinical outcomes shows the target complexity within the human host (including the CNS, blood, lungs, eyes, muscles, bladder and skin), and several medical specialties have to be involved in the care and treatment of infected and diseased persons [17-27]. 
HTLV is an ancient infection in humans and alternates between persistence and productive cycles, which favors an effective mechanism involving vertical and horizontal transmission. According to the geographical environment and behavioral risk factors, the increased risk of transmission of the virus increases the prevalence and incidence of infection and disease [6, 28-32].

Viral dispersion in the human body leads to the infection of several biological fluids, including the blood, semen, vaginal fluid, and milk and results in its vertical transmission from mother to child (via the placenta and perinatal breast feeding), the injection of drugs, the transfusion of blood and its components, the transplantation of organs and the engagement in sexual relations $[29,33-38]$. Each of these plays an important role in viral maintenance. The risk associated with transfusion used to be major but it decreased sharply with the introduction of strict regulatory policies regarding blood screening in Brazil and elsewhere [39-41]. The recommended policy of avoiding breastfeeding in mothers who carry the virus is generally followed in urban areas and is an efficient procedure whereby transmission is reduced.

Vertical transmission is common and is probably the most important route for the maintenance of HTLV within epidemiologically closed communities, as seen with HTLV-2c among Indians communities in the Amazon area of Brazil and in urban areas [6, 33, 42-44]. Among the Guaymi in Panama, there are relatively more infected children born from infected mothers [28, 45], and among the Kubenkokre, Kayapo villagers in the Amazon region of Brazil, familial cluster studies have showed the transmission of the virus crossing one or more generations, and more than $20 \%$ of the children under 9 years of age are infected [6]. Molecular evidence has clearly showed that the virus is transmitted from mother to child among isolated Indian tribes, which illustrates the importance of the mechanism for the maintenance of the high endemicity of the virus $[33,36]$.

The geographical distribution of the virus is influenced by the transmission route used. In North America, HTLV-2 was probably spread from American Indians to injection drug users (IDUs), which resulted in the transmission of the virus to other IDU communities in Europe and was the most likely route that carried HTLV to Vietnam, during the war in 1960-1970 [46-49]. In the Amazon region of Brazil, injecting drugs was not an important route for the spread and maintenance of HTLV-1/2 in urban, nonurban, or isolated communities or in co-infection with HIV-1 $[50,51]$ in a clear contrast to what was usually seen in other areas of Brazil, where the use of illicit drugs is a well-known risk factor for both virus infections [52-54]. More recently, high prevalence rates and levels of genetic diversity of both HTLV-1 and
HTLV-2 were shown among illicit drug users in the State of Para [55], which is a change in the epidemiological pattern of the spread of the two viruses in the region.

Sexual transmission is certainly the most important transmission route for HTLV-1 and HTLV-2 and serves as an efficient mechanism for the spread of HTLV-2c among native Indian groups $[6,28,56]$. In urban areas, HTLV infection is more common among women [42, $57,58]$. Within epidemiologically closed communities such as Indian populations, the distribution of antibodies against HTLV shows that the prevalence increases with increasing age and is not different between males and females; this is evidence of an equal efficiency of transmission from men to women and from women to men $[6,28,56]$ with the aid of vertical transmission acting by chance to infect both sexes equally. It is worth mentioning that it is not commonly observed in urban areas [42].

The description of HTLV-1 and HTLV-2 soon led to seroepidemiological studies based on the detection of antibodies against HTLV, which is the usual approach to determine the initial prevalence rates of HTLV according to geographical locations, age and sex, among other variables. Few studies have been conducted strictly with controlled populations to verify the published information from the 1980s and 1990s. Consequently, there have been few attempts to establish the trends in prevalence and incidence rates and the spread of HTLV in Brazil and, particularly in the Amazon region of the country.

\section{Detection of HTLV in the Amazon region of Brazil}

HTLV-1 was described in 1980, and HTLV-2 was described in 1982 [59-62]. Soon, knowledge of their geographical distribution was expanded through the production of seroepidemiological data, which clearly defined the low prevalence (up to 1\%) but almost universal presence of HTLV-1 among specific populations (in Europe, the Americas, the Caribbean, and sub-Saharan Africa), reaching more than $30 \%$ in some areas of southern Japan [63-66].

HTLV-2, however, showed a distribution limited to intravenous drug users in the USA, Europe, Southeast Asia and among American Indians from North America to South America as well as in the Pygmy tribes in Central Africa [6, 47-49, 66-72]. The prevalence rates were generally low (except for the hyperendemicity among some Amazonian Indian communities), and the association with disease was substantial with HTLV-1 and not usually common with HTLV-2 [73]. In Brazil, associated diseases were initially described in different geographical areas and in specific groups, including blood donors and patients with hematological and neurological diseases [74-83]. 
In the Amazon region of Brazil, HTLV-1 and HTLV-2 infections were primarily described [63, 84-86], and soon their geographical dissemination expanded [6]. In 1998, HTLV-2 was detected for the first time outside native Indian communities, and both viruses were found in blood donors [82] and HIV-1 carriers [50]. The first cases of diseased persons were described with HTLV1-associated myelopathy/tropical spastic paraparesis (HAM/TSP) among persons residing on Marajo Island [83], and the presence of both viruses on the east coast of the island was also identified on Afro-descendants [87]. HTLV-1 was described among sex workers, and for the first time, there was a clear geographical link when the virus was identified among Japanese immigrants in the Amazon originating from Kyushu, a highly endemic area of HTLV-1 in Japan [88].

HTLV human infections in the Amazon region of Brazil have been recorded by several studies that considered widely different populations, including blood donors, pregnant women, urban familial aggregates and native indigenous people. These investigations comprise the epidemiological picture in the North region of the country and will be presented and discussed further in the following sections.

\section{The Amazon region of Brazil}

The Amazon is a large geographical area involving six countries, and Brazil holds the largest area in the system. The Amazon region of Brazil (ARB) involves nine federative States and an area of 5.1 million $\mathrm{km}^{2}$, which represents $60 \%$ of the country but is inhabited by approximately $15 \%$ of the Brazilian population.

There is a large difference in demographic, social, cultural and development between the ARB and the rest of the country, which is evidenced in some commonly used markers related to the health and education of the population and its level of welfare and development. Historically, the ARB was always left behind by policies given that the population of the region represents only $13 \%$ of the gross internal revenue of the country, has a higher rate of illiteracy (12.9\% vs. $10.2 \%)$, a slightly higher infant mortality rate (18.6 vs. 15.9 per 1000$)$ and a lower life expectancy (72 vs. 76 years) in comparison to the other areas of Brazil [89].

On the other hand, the ARB is a unique geographical area, considering the diversity of humans and other living species. Approximately half of the so far undescribed living organisms on earth (plants, vertebrates, and microorganisms, among others) reside within the ARB [90].

The history of HTLV is a fascinating one regarding its possible origin in the African continent and its spread in different directions according to human migration routes [4], and the ARB is of paramount importance because of the presence of a specific strain of the virus that originated during human migration into the area and its further dissemination to other geographical areas in the country and abroad [36, 51, 91-97].

\section{Epidemiological data of HTLV-1 and HTLV-2 in the Amazon region of Brazil}

Human infections by HTLV in the Amazon region of Brazil have been recorded by several studies involving blood donors [82, 98-102], pregnant women [103-106], urban familial aggregates [42] and native Indians [6, 56] (Fig. 1).

The isolation of HTLV-1 and HTLV-2 led to the manufacturing of serological assays to detect human antibodies against the viruses, and several studies were immediately performed describing prevalence rates around the world. South American countries reported quite different figures with large variations, including in Argentina (0.07\%), Chile $(0.73 \%)$, Venezuela (6.8\%), Colombia, where the prevalence was higher in low geographical areas (4.3\%) than in higher areas $(0.73 \%)$ of the country, and in French Guiana (6.7-13.1\%) [107-110]. It is important to bear in mind that these figures are rarely comparable as there are no uniformity of the different population groups investigated (age, sex, sampling, laboratory assays, among others). It is relevant to mention that the same variables are the cause to find such conflicting figures also described in Brazil where the mean prevalence was initially thought to be approximately $0.41 \%$, but there was a large range of prevalence rates from $0.08 \%$ in Manaus and Florianopolis to $1.35 \%$ in Salvador [98]. It was common to use serological assays prepared with different strains of HTLV and different targets of the reagents to detect the antibodies, and this technique is one of the possible reasons for such a variation in the figures found.

In a second round of prevalence studies, a more comprehensive investigation was conducted with national public blood banks [100], and the figures were found to be clearly different. There was a range from $0.4 / 1000$ in the State of Santa Catarina (southern part of the country) to 10/1000 in the State of Maranhao (in the northeast). In the Amazon region of Brazil, the prevalence ranged from $1 / 1000$ in the State of Rondonia to 9.1/1000 in the State of Para [100]. For the purpose of the geopolitical division of the country and economic development, the so-called Amazonia Legal includes three other states: Maranhao, Tocantins and Mato Grosso. Some of the present information and discussion will also include the State of Maranhao.

The main issue of concern presented is the large variation obtained by the different investigations conducted in the same geographical area. The data include the states in the North region of the country, but the results are not different from those in the rest of the country. The 


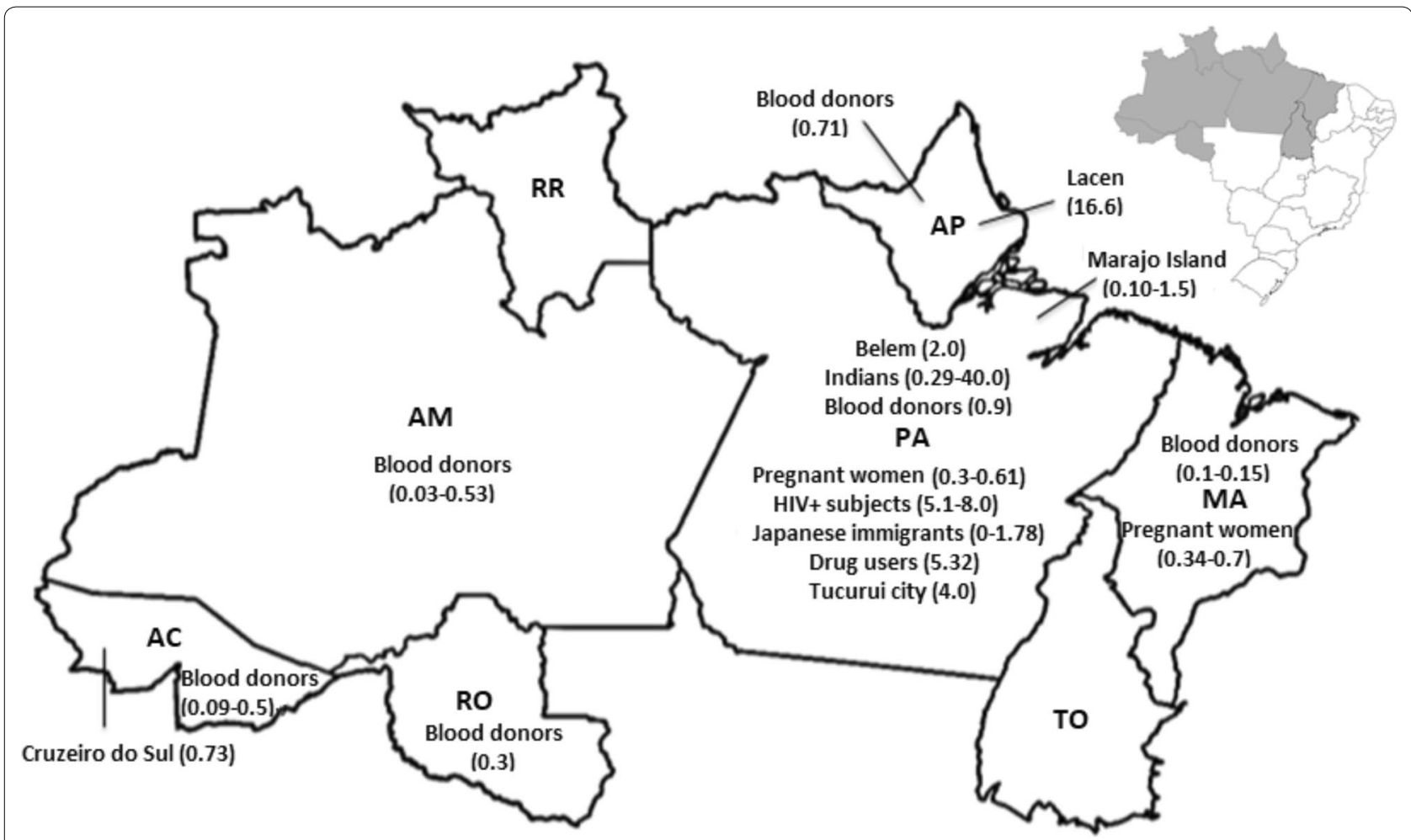

Fig. 1 Representation of the Amazon region of Brazil with the results of prevalence rates of HTLV-1/2 infection in population groups

discrepancy is shown in Table 1, which summarizes the figures obtained in the different studies.

In Rio Branco (Acre), the investigation of HTLV among blood donors showed that using two enzyme immunoassays, the results were significantly different $(0.66 \%$ vs. $0.11 \%$ of 11,121 samples); the Western blot results confirmed the presence of antibodies in 8 samples for HTLV-1 and 2 for HTLV-2. PCR results confirmed one HTLV-1 and one HTLV-2 reaction. The study shows the nature of conflicting results when comparing those with later results: $0.09 \%$ [99] and 0.5\% [100]. Mota-Miranda et al. [101] investigated the molecular epidemiology of HTLV- 1 and described a prevalence rate of $0.46 \%$ among blood donors in 2004, although the sample was smaller than the first investigation by the local group. The state of Acre is an endemic area for malaria, an additional variable that might add confusion because of the misinterpretation of results owing to cross-reactions against HTLV-1 detected in patients infected with Plasmodium sp. [111]. Even though, a prevalence of $0.73 \%$ was detected among the general population of Cruzeiro do Sul, where malaria is endemic. There was a strong expectation of high prevalence rates in the State of Acre considering the Indians racial mixture of the general population, but so far, there is no evidence of wide distributions of the two viruses.
In Manaus (Amazonas State), the results are also conflicting. The initial prevalence was set at $0.08 \%$ [98] and was later described as $0.53 \%$ [100] and $0.14 \%$ [112] for HTLV-1/2 among blood donors in urban areas. Two other relevant investigations showed that HTLV infection was not present among pregnant women [105] or patients presenting with skin diseases (including dermatitis), leishmaniasis and leprosy [112]. More recently, data were published related to a retrospective prevalence of antibodies in a large group of blood donors $(n=87,402)$ who were initially screened from 2001 to 2003; however, only 24 persons were confirmed to be infected by HTLV-1 and HTLV-2, which shows the low prevalence of infection in the city of Manaus [113].

The presence of the virus in different areas and populations in the State of Amapa has been investigated a few times, and low prevalence rates of infection (0.71\%) have been found among blood donors [100]. The viruses were not found in HIV-1 infected persons $[114,118]$ or in a quilombo (Afro-descendants in isolated communities that were originally founded by escaped slaves); however, HTLV-1 was found to be present (5/30) among individuals seeking a serological diagnosis in a public health laboratory [114].

In Sao Luiz, the capital city of the State of Maranhao, the highest prevalence rate (1\%) among blood banks in 
Table 1 Prevalence rates of HTLV-1/2 infection in population groups of the Amazon region of Brazil

\begin{tabular}{|c|c|c|c|c|c|c|c|}
\hline Location & Group & Sample size & $\begin{array}{l}\text { Prevalence rate } \\
\text { HTLV (\%) }\end{array}$ & HTLV-1 (n) & HTLV-2 (n) & $\operatorname{HTLV}(n)^{a}$ & Reference (\#) \\
\hline Rondonia & Blood donors & - & $0.3^{\mathrm{a}}$ & - & - & - & {$[100]$} \\
\hline \multirow[t]{4}{*}{ Acre } & Blood donors & 11,121 & 0.09 & 9 & 3 & - & [99] \\
\hline & Blood donors & - & $0.5^{\mathrm{a}}$ & - & - & 5 & {$[100]$} \\
\hline & Blood donors & 219 & 0.46 & 1 & 0 & - & [101] \\
\hline & Cruzeiro do Sul & 136 & 0.73 & 1 & 0 & - & [111] \\
\hline \multirow[t]{6}{*}{ Amazonas } & Blood donors & 1200 & 0.08 & 1 & - & - & [98] \\
\hline & Blood donors & - & $0.53^{\mathrm{a}}$ & - & - & - & {$[100]$} \\
\hline & Blood donors & 6865 & 0.14 & - & - & - & [112] \\
\hline & Pregnant women & 674 & 0 & - & - & - & [105] \\
\hline & Skin diseases & 1091 & 0 & - & - & - & [112] \\
\hline & Blood donors & 87,402 & 0.03 & 16 & 5 & 3 & [113] \\
\hline \multirow[t]{5}{*}{ Amapa } & Blood donors & - & $0.71^{\mathrm{a}}$ & - & - & - & {$[100]$} \\
\hline & Afrodescendants & 186 & 0 & - & - & - & [114] \\
\hline & HIV-1 & 52 & 0 & - & - & - & [118] \\
\hline & HIV-1 & 140 & 0 & - & - & - & [114] \\
\hline & Lacen & 30 & 16,6 & 5 & - & - & [114] \\
\hline \multirow[t]{4}{*}{ Maranhao } & Blood donors & - & $0.1^{\mathrm{a}}$ & - & - & - & {$[100]$} \\
\hline & Pregnant women & 2044 & 0.34 & 4 & 3 & - & [104] \\
\hline & Pregnant women & 324 & 0.7 & 5 & & & [115] \\
\hline & Blood donors & 365,564 & $0.15^{\mathrm{a}}$ & - & - & $72^{\mathrm{a}}$ & {$[102]$} \\
\hline \multirow[t]{18}{*}{ Para } & Indians & 137 & $31.4^{\mathrm{a}}$ & 43 & - & - & [84] \\
\hline & Indians & 209 & 10.5 & 22 & - & - & [85] \\
\hline & Blood donors & - & $0.9^{\mathrm{a}}$ & - & - & - & [100] \\
\hline & Indians & 314 & 7.6 & 1 & 18 & 5 & {$[63]$} \\
\hline & Indians & 1324 & $0-40$ & 5 & 104 & - & [6] \\
\hline & Indians & 177 & 5.1 & - & 9 & - & [51] \\
\hline & Indians & 263 & 0.29 & - & 77 & - & {$[56]$} \\
\hline & Pregnant women & 13,382 & 0.3 & 39 & 1 & - & [103] \\
\hline & Pregnant women & 324 & 0.61 & 2 & 0 & - & [106] \\
\hline & Tucurui & 657 & $4.7^{\mathrm{a}}$ & - & - & - & [116] \\
\hline & Belem & 1059 & 2 & 15 & 5 & - & [117] \\
\hline & HIV-1 & 149 & 8.0 & 4 & 7 & 1 & {$[50]$} \\
\hline & HIV-1 & 117 & 5.1 & 2 & 4 & - & [118] \\
\hline & Japaneses & 44 & 0 & - & - & - & [85] \\
\hline & Japanese & 168 & 1.78 & 3 & - & - & [88] \\
\hline & $\begin{array}{l}\text { Afrodescendants } \\
\text { (Marajo Island) }\end{array}$ & 259 & 1.5 & 3 & 1 & - & [87] \\
\hline & Marajo Island & 1899 & 0.10 & 2 & - & - & [94] \\
\hline & Drug users & 826 & 5.32 & 25 & 19 & - & [55] \\
\hline
\end{tabular}

${ }^{a}$ Tested only by enzyme immune assay (ELISA)

Brazil was identified [100], but the prevalence rate among pregnant women ranged from $0.34 \%$ (HTLV-1, $0.19 \%$ and HTLV-2, 0.15\%) [104] to $0.7 \%$ (HTLV-1 only) more recently described [115]. Retrospective information on blood donors showed that only $0.15 \%$ among more than 365,000 persons tested in the period 2003-2009 were positive for HTLV-1/2 [102], however only 53 persons confirmed the seroreactivity. The frequencies of the identification of both viruses are not significantly different, but again the general prevalence showed figures that are somewhat lower than what was usually expected and previously described in the State of Maranhao.

The State of Para has been the site of the majority of epidemiological studies intending to define prevalence 
rates of antibodies against $\mathrm{HTLV}-1 / 2$ with a variety of different populations, and several conflicting results have been obtained. The initial figures indicated that the prevalence rates measured by immunoenzymatic assays ranged from $3.6 \%$ to more than $30 \%$ for HTLV1 , mostly among Indians populations $[84,85]$, that the rate was $0.91 \%$ among those undergoing blood donation screening [100]. A large distribution of HTLV-2 was shown among Indians communities not only in the State of Para but also in the Amazon area of Brazil, reaching confirmed prevalence rates of more than $40 \%[6,51,56$, 63] among some Indian communities and the detection of a new molecular subtype (HTLV-2c) that was soon also described in urban areas outside of the ARB [6, 33, 50, 51, 116]. Prevalence studies also provide interesting information, such as the description of HTLV-2b among blood donors in Belém, which stresses the need for ongoing molecular epidemiology investigations [116]. A comprehensive investigation detected HTLV-1 among 0.3\% $(\mathrm{n}=39)$ of 13,382 pregnant women in Belém and one person infected with HTLV-2 [103]. Later, another prevalence rate of $0.61 \%$ was detected in pregnant women in Belém [106]. A prevalence rate (4.7\%) of antibodies against HTLV, detected by enzyme immune assay, was described among residents along the shores of the Tucurui hydroelectric power plant [117]. This was a rather high figure for urban communities, however there was no confirmation of reactivity by other laboratory methods. The most recent investigation in Belém considered the prevalence of antibodies against HTLV among 1059 inhabitants and showed a $2 \%$ positivity for antibodies against both HTLV-1 $(n=15)$ and HTLV-2 $(n=5)$ [118].

Two different studies dealt with HTLV/HIV-1 coinfections. The first approach found a prevalence rate of $8 \%(12 / 149)$ for individuals, mostly males $(\mathrm{n}=10)$, positive for HTLV-1 $(\mathrm{n}=4)$ and HTLV-2 $(\mathrm{n}=7)$ [50]. A later approach detected a prevalence rate of $5.1 \%(6 / 117)$ for co-infections [119] with HTLV-1 $(\mathrm{n}=02)$ and HTLV-2 $(\mathrm{n}=04)$, and those individuals were mostly female $(\mathrm{n}=4)$. This clearly indicated the change in sex predominance in the HIV-1 epidemic in the city of Belém.

The initial approach of Japanese immigrants did not result in HTLV reactivity [85], but later, the prevalence of $1.78 \%$ of HTLV-1 was found in immigrants from Kyushu residing in the ARB [88]. The Marajo Archipelago also showed different figures according to the population group investigated. It was higher in an epidemiologically semi-closed quilombo than the average of four municipalities $(1.5 \%$ vs. $0.1 \%$, respectively) investigated [ 87 , 94]. Since the initial detection of HAM/TSP in patients from the Marajo Archipelago, in the North region of Brazil [83], HTLV-1-infected male and female patients with different signs of clinical severity of neurological disease have been described [20]. Although there have been continuous descriptions of persons with other diseases, including dermatological symptoms [120], no hematological disorders, so far, have been associated with HTLV-1 infection in the ARB.

Fairly rapid changes in the epidemiology of HTLV-1/2 are occurring in the ARB. A recent and extensive study was performed in the State of Para, which detected an intermediate prevalence of $4.3 \%$ with almost the same frequencies of HTLV-1 $(n=25)$ and HTLV-2 $(n=19)$ among drug users [55]. Both viruses are widely distributed in the Amazon region of Brazil and particularly among this population, who especially need close attention in terms of the control and prevention of infection as they are key participants in the spread of the virus.

\section{Conclusions}

Epidemiological studies in the ARB, as in other areas of the country and abroad, have been plagued by imprecise sampling ("grab samples" was common), which generated inadequate and conflicting results among several studies. Groups of sub-populations were consistently chosen, with the equivocal assumption of a general figure for most of the region, leading to a selection bias that rendered untrustworthy results. The selection of blood donors, the selection of diseased population subgroups, and the retrospective collection of data are some of the examples that should be avoided in future prevalence studies. Relevant population groups should be selected and preferably using multiple centers of study working together to increase sample size. It is relevant to stress that confirmatory tests should be always used to make sure the information is not equivocal and the absence of correct information should be put ahead to avoid misinterpretations. Urban populations should be the optimal target to answer important questions such as the following: who is mostly affected by this neglected infection? Who should receive future preventive measures such as vaccines? Which risk factors are relevant for the transmission of the virus?

HTLV-1 is an important human pathogen and the only human retrovirus associated with a large array of diseases, including lymphoma/leukemia. However, in the possible event of the development of a vaccine in the near future, health authorities will not be able to immediately define the population at risk who should receive it, either in the ARB or in other areas of the country. New and authoritative epidemiological information should be gathered to gauge the actual need for such a product. Australian aboriginal people are examples of persons at high risk for morbidity and mortality associated with the wide dissemination and high prevalence of HTLV-1. Respiratory diseases recently also 
described in the ARB [121] are new and dangerous facets of the infection that can truncate productive lives, which is a compelling reason to revitalize HTLV-1 epidemiological studies in the ARB, elsewhere in the country and worldwide.

Small epidemiologically closed or semi-closed human aggregates are easier with regard to the implementation of preventive measures, although transmission in such communities is further enhanced by the mother to child transmission route in utero, during birth and during breast feeding both perinatal and after birth, which corroborates the formation of familial aggregates. The most recent report from our laboratory has shown that Asurini and Arawete Indian tribes have remained free from HTLV-1/2 infections due to cultural and social isolation from the infected neighboring tribes and villages [122]. Indian communities from the North region of Brazil usually experience hyperendemic infections with HTLV-2, which is less pathogenic than HTLV1 ; this is a more favorable situation compared to what is found among native aboriginal people in Australia, where hyperendemicity exists with the more pathogenic HTLV-1 [30, 123].

It is reasonable to infer that the general prevalence of the virus should be decreasing because of the general policies regarding testing blood donations and some efforts to disseminate general knowledge of the virus, but so far this has not been substantiated, as conflicting prevalence results generate confusion regarding the adequate delivery of information. National associations of HTLV-infected persons are active and give full support to the elimination of the virus, but their messages are not always disseminated through the appropriate channels. Although the existing preventive campaigns are not aggressive, they should receive full official support to attain success in the future, particularly as proposals are being made with regard to virus eradication [124].

\section{Abbreviations}

HTLV: Human T-lymphotropic virus; HAM/TSP: HTLV-1 associated myelopathy/ tropical spastic paraparesis; ARB: Amazon region of Brazil; PCR: Polymerase chain reaction

\section{Acknowledgements}

We thank Conselho Nacional de Desenvolvimento Científico e TecnológicoCNPQ and Universidade Federal do Para.

\section{Authors' contributions}

RI, MOGI and ACRV wrote the manuscript. All authors read and approved the final manuscript.

\section{Funding}

This investigation was fully supported by grants from the Conselho Nacional de Desenvolvimento Científico e Tecnológico-CNPq (Grants \#301869/20170, \#312979/2018-5 and \#442522/2019-3) and Universidade Federal do Pará (PAPQ/2019).
Availability of data and materials

Not applicable.

Ethics approval and consent to participate

Not applicable.

Consent for publication

Not applicable.

Competing interests

The authors declare that they have no competing interests.

Received: 21 November 2019 Accepted: 9 February 2020

Published online: 14 February 2020

References

1. ICTV - International Commitee on Taxonomy of Viruses. Taxonomy history: primate T-lymphotropic virus 1; 2017. https://talk.ictvonline.org/ taxonomy/p/taxonomy-history?taxnode_id=20164226. Acessed 10 Nov 2019.

2. Miura T, Fukunaga T, Igarashi T, Yamashita M, Ido E, Funahashi S, et al. Phylogenetic subtypes of human T-lymphotropic virus type I and their relations to the anthropological background. Proc Natl Acad Sci USA. 1994:91:1124-7.

3. Ureta-Vidal A, Gessain A, Yoshida M, Mahieux R, Nishioka K, Tekaia F, et al. Molecular epidemiology of HTLV type I in Japan: evidence for two distinct ancestral lineages with a particular geographical distribution. AIDS Res Hum Retrovir. 1994;10:1557-66.

4. Van Dooren S, Salemi M, Vandamme AM. Dating the origin of the African human T-cell lymphotropic virus type-I (HTLV-I) subtypes. Mol Biol Evol. 2001;18:661-71.

5. Hall WW, Takahashi H, Liu C, Kaplan MH, Scheewind O, ljichi S, et al. Multiple isolates and characteristics of human T-cell leukemia virus type II. J Virol. 1992;66:2456-63.

6. Ishak R, Harrington WJ, Azevedo VN, Eiraku N, Ishak MOG, Guerreiro JF, et al. Identification of human T cell lymphotropic virus type lla infection in the Kayapo, an Indigenous population of Brazil. AIDS Res Hum Retrovir. 1995:11:813-21.

7. Eiraku N, Novoa P, Ferreira MDC, Monken C, Ishak R, Ferreira ODC, et al. Identification and characterization of a new and distinct molecular subtype of human T-cell lymphotropic virus type 2. J Virol. 1996;70:1481-92.

8. Vandamme AM, Salemi M, Van Brussel M, Liu HF, Van Laethem K, Van Ranst $M$, et al. African origin of human T-lymphotropic virus type 2 (HTLV-2) supported by a potential new HTLV-2d subtype in Congolese Bambuti Efe Pygmies. J Virol. 1998;72:4327-40.

9. Wolfe ND, Heneine W, Carr JK, Garcia AD, Shanmugam V, Tamoufe $U$, et al. Emergence of unique primate T-lymphotropic viruses among central African bushmeat hunters. Proc Natl Acad Sci USA. 2005; 102:7994-9.

10. Perzova R, Benz P, Abbott L, Welch C, Thomas A, Ghoul RE, et al. Short communication: no evidence of HTLV-3 and HTLV-4 infection in New York state subjects at risk for retroviral infection. AIDS Res Hum Retrovir. 2010;26:1229-31.

11. Duong YT, Jia H, Lust JA, Garcia AD, Tiffany AJ, Heneine W, et al. Short communication: absence of evidence of HTLV-3 and HTLV-4 in patients with large granular lymphocyte (LGL) leukemia. AIDS Res Hum Retrovir. 2008;24:1503-5.

12. Baltimore D. Viral RNA-dependent DNA polymerase: RNA-dependent DNA polymerase in virions of RNA tumour viruses. Nature. 1970;226:1209-11.

13. Temin HM, Mizutani S. Viral RNA-dependent DNA polymerase: RNAdependent DNA polymerase in virions of rous sarcoma virus. Nature. 1970;226:1211-3.

14. Cook LB, Rowan AG, Melamed A, Taylor GP, Bangham CRM. HTLV-1infected T cells contain a single integrated provirus in natural infection. Blood. 2012;120:3488-90.

15. Zhang W, Cao S, Martin JL, Mueller JD, Mansky LM. Morphology and ultrastructure of retrovirus particles. AIMS Biophys. 2015;2:343-69. 
16. Kirk PDW, Huvet M, Melamed A, Maertens GN, Bangham CRM. Retroviruses integrate into a shared, non-palindromic DNA motif. Nat Microbiol. 2016;2:16212.

17. Silva Marcus T, Coutinho F, Leite Ana C, Harab Ramza C, Araújo A, Andrada-Serpa Maria J. Isolated bladder dysfunction in human T lymphotropic virus type 1 infection. Clin Infect Dis. 2009;48:e34-6.

18. Martin F, Taylor GP, Jacobson S. Inflammatory manifestations of HTLV-1 and their therapeutic options. Expert Rev Clin Immunol. 2014:10:1531-46.

19. Araujo AQC. Update on neurological manifestations of HTLV-1 infection. Curr Infect Dis Rep. 2015;17:459.

20. Dias GAS, Yoshikawa GT, Koyama RVL, Fujihara S, Martins LCS, Medeiros $R$, et al. Neurological manifestations in individuals with HTLV-1-associated myelopathy/tropical spastic paraparesis in the Amazon. Spinal Cord. 2016;54:154-7.

21. Dias ARN, Falcão LFM, Falcão ASC, Normando VMF, Quaresma JAS Human T lymphotropic virus and pulmonary diseases. Front Microbiol. 2018;9:1879.

22. Chew R, Henderson T, Aujla J, Whist E, Einsiedel L. Turning a blind eye: HTLV-1-associated uveitis in Indigenous adults from Central Australia. Int Ophthalmol. 2018;38:2159-62.

23. Nakao K, Abematsu N, Sakamoto T. Systemic diseases in patients with HTLV-1-associated uveitis. Br J Ophthalmol. 2018;102:373-6.

24. Kamoi K, Okayama A, Izumo S, Hamaguchi I, Uchimaru K, Tojo A, et al. Adult T-cell leukemia/lymphoma-related ocular manifestations: analysis of the first large-scale nationwide survey. Front Microbiol. 2019;9:3240.

25. Kako S, Joshita S, Matsuo A, Kawaguchi K, Umemura T, Tanaka E. A case of adult T-cell leukemia/lymphoma complicated with bilateral chylothorax. Case Rep Oncol Med. 2019;2019:8357893.

26. Bimbi C, Brzezinski P, Sokolowska-Wojdylo M. Crusted (Norwegian) scabies as a strong marker of adult T-cell leukemia/lymphoma in HTLV-1 infection. Clin Case Rep. 2019;7:474-6.

27. Mohammadi FS, Mosavat A, Shabestari M, Ghezeldasht SA, Shabestari M, Mozayani F, et al. HTLV-1-host interactions facilitate the manifestations of cardiovascular disease. Microb Pathog. 2019;134:103578.

28. Lairmore MD, Jacobson S, Gracia F, De BK, Castillo L, Larreategui M et al. Isolation of human T-cell lymphotropic virus type 2 from Guaymi Indians in Panama. Proc Natl Acad Sci USA. 1990;87:8840-4.

29. Gessain A, Cassar O. Epidemiological aspects and world distribution of HTLV-1 infection. Front Microbiol. 2012;3:388.

30. Einsiedel L, Woodman RJ, Flynn M, Wilson K, Cassar O, Gessain A. Human T-lymphotropic virus type 1 infection in an Indigenous Australian population: epidemiological insights from a hospital-based cohort study. BMC Public Health. 2016;16:797.

31. Caron M, Besson G, Padilla C, Makuwa M, Nkoghe D, Leroy E, et al. Revisiting human T-cell lymphotropic virus types 1 and 2 infections among rural population in Gabon, central Africa thirty years after the first analysis. PLoS Negl Trop Dis. 2018;12:e0006833.

32. Paiva AM, Assone T, Haziot MEJ, Smid J, Fonseca LAM, Luiz ODC, et al. Risk factors associated with HTLV-1 vertical transmission in Brazil: longer breastfeeding, higher maternal proviral load and previous HTLV-1-infected offspring. Sci Rep. 2018;8:7742.

33. Ishak $R$, Vallinoto ACR, Azevedo VN, Lewis M, Hall WW, Ishak MOG. Molecular evidence of mother-to-child transmission of HTLV-Ilc in the Kararao Village (Kayapo) in the Amazon region of Brazil. Rev Soc Bras Med Trop. 2001;34:519-25

34. Moriuchi M, Moriuchi $\mathrm{H}$. Seminal fluid enhances replication of human T-cell leukemia virus type 1: implications for sexual transmission. J Virol. 2004;78:12709-11.

35. Lairmore MD, Anupam R, Bowden N, Haines R, Haynes RA, Ratner L, et al. Molecular determinants of human T-lymphotropic virus type 1 transmission and spread. Viruses. 2011;3:1131-65.

36. Vallinoto ACR, Ishak R. HTLV-2: uma infecção antiga entre os povos indígenas da Amazônia Brasileira. Rev Pan-Amazônica de Saúde. 2017:8:7-9.

37. de Mendoza C, Roc L, Benito R, Reina G, Ramos JM, Gómez C, et al. HTLV-1 infection in solid organ transplant donors and recipients in Spain. BMC Infect Dis. 2019;19:706.

38. Rosadas C, Taylor GP. Mother-to-Child HTLV-1 transmission: unmet research needs. Front Microbiol. 2019;10:999.
39. Dias-Bastos MR, Oliveira CDL, Carneiro-Proietti ABDF. Decline in prevalence and asymmetric distribution of human T cell lymphotropic virus 1 and 2 in blood donors, State of Minas Gerais, Brazil, 1993 to 2007. Rev Soc Bras Med Trop. 2010;43:615-9.

40. Carneiro-Proietti ABF, Sabino EC, Leão S, Salles NA, Loureiro P, Sarr M, et al. Human T-lymphotropic virus type 1 and type 2 seroprevalence, incidence, and residual transfusion risk among blood donors in Brazil during 2007-2009. AIDS Res Hum Retroviruses. 2012;28:1265-72.

41. Murphy EL. Infection with human T-lymphotropic virus types-1 and -2 (HTLV-1 and -2): implications for blood transfusion safety. Transfus Clin Biol. 2016;23:13-9.

42. Da Costa CA, Furtado KCYO, Ferreira LDSC, Almeida DDS, Linhares ADC, Ishak $R$, et al. Familial transmission of human T-cell lymphotrophic virus: silent dissemination of an emerging but neglected infection. PLoS Negl Trop Dis. 2013;7:e2272.

43. Percher F, Jeannin P, Martin-Latil S, Gessain A, Afonso P, Vidy-Roche A, et al. Mother-to-child transmission of HTLV-1 epidemiological aspects, mechanisms and determinants of mother-to-child transmission. Viruses. 2016;8:E40.

44. Frutos MC, Gastaldello R, Balangero M, Remondegui C, Blanco S, Otsuki $\mathrm{K}$, et al. Silent dissemination of HTLV-1 in an endemic area of Argentina. Epidemiological and molecular evidence of intrafamilial transmission. PLoS ONE. 2017;12:e0174920.

45. Vitek CR, Gracia FI, Giusti R, Fukuda K, Green DB, Castillo LC, et al. Evidence for sexual and mother-to-child transmission of human $T$ lymphotropic virus type II among Guaymi Indians, Panama. J Infect Dis. 1995;171:1022-6.

46. Vallejo A, Ferrante P, Soriano V, Calabrò ML, Mancuso R, Heredia A, et al. Nucleotide sequence and restriction fragment-length polymorphism analysis of human T-cell lymphotropic virus type II (HTLV-II) in Southern Europe: evidence for the HTLV-Ila and HTLV-IIb subtypes. J Acquir Immune Defic Syndr Hum Retrovirol. 1996;13:384-91.

47. Fukushima Y, Lewis MJ, Monken C, Komuro K, Kusagawa S, Sato H, et al. Short communication: identification and molecular characterization of human T lymphotropic virus type II infections in intravenous drug abusers in the former south Vietnam. AIDS Res Hum Retroviruses. 1998; 14:537-40.

48. Salemi M, Vandamme A-M, Gradozzi C, Van Laethem K, Cattaneo E, Taylor G, et al. Evolutionary rate and genetic heterogeneity of human T-cell lymphotropic virus type II (HTLV-II) using isolates from European injecting drug users. J Mol Evol. 1998;46:602-11.

49. Egan JF, O'Leary B, Lewis MJ, Mulcahy F, Sheehy N, Hasegawa H, et al. High rate of human $T$ lymphotropic virus type lla infection in HIV type 1-infected intravenous drug abusers in Ireland. AIDS Res Hum Retrovir. 1999;15:699-705

50. Vallinoto ACR, Azevedo VN, Santos DEM, Caniceiro S, Mesquita FCL, Hall WW, et al. Serological evidence of HTLV-I and HTLV-Il coinfections in HIV-1 positive patients in Belém, state of Pará. Brazil. Mem Inst Oswaldo Cruz. 1998:93:407-9.

51. Vallinoto ACR, Ishak MOG, Azevedo VN, Vicente ACP, Otsuki K, Hall WW, et al. Molecular epidemiology of human T-lymphotropic virus type II infection in Amerindian and urban populations of the Amazon region of Brazil. Hum Biol. 2002:74:633-44.

52. Brites C, Harrington W, Pedroso C, Netto E, Badaró R. Epidemiological characteristics of HTLV-I and II co-infection in Brazilian subjects infected by HIV-1. Braz J Infect Dis. 1997;1:42-7.

53. Dourado I, Andrade T, Carpenter CL, Galvão-Castro B. Risk factors for human T cell lymphotropic virus type I among injecting drug users in northeast Brazil: possibly greater efficiency of male to female transmission. Mem Inst Oswaldo Cruz. 1999:94:13-8.

54. Nunes CLX, Andrade T, Galvão-Castro B, Bastos FI, Reingold A. Assessing risk behaviors and prevalence of sexually transmitted and blood-borne infections among female crack cocaine users in salvador-Bahia, Brazil. Braz J Infect Dis. 2007;11:561-6.

55. Oliveira-Filho AB, Araújo APS, Souza APC, Gomes CM, Silva-Oliveira GC, Martins LC, et al. Human T-lymphotropic virus 1 and 2 among people who used illicit drugs in the state of Pará, northern Brazil. Sci Rep. 2019:9:14750

56. Braço ILJ, de Sá KSG, Waqasi M, Queiroz MAF, da Silva ANR, CayresVallinoto IMV, et al. High prevalence of human T-lymphotropic virus 
2 (HTLV-2) infection in villages of the Xikrin tribe (Kayapo), Brazilian Amazon region. BMC Infect Dis. 2019;19:459.

57. Satake M, Yamaguchi K, Tadokoro K. Current prevalence of HTLV-1 in Japan as determined by screening of blood donors. J Med Virol. 2012;84:327-35.

58. Hananiya HS, Ella EE, Aminu M, Anyanwu NCJ. Prevalence of human T-cell lymphotropic virus and the socio-demographic and risk factors associated with the infection among post-natal clinics women in Zaria, Nigeria. J Immunoassay Immunochem. 2019;40:485-94.

59. Poiesz BJ, Ruscetti FW, Gazdar AF, Bunn PA, Minna JD, Gallo RC. Detection and isolation of type $C$ retrovirus particles from fresh and cultured lymphocytes of a patient with cutaneous T-cell lymphoma. Proc Natl Acad Sci USA. 1980;77:7415-9.

60. Poiesz BJ, Ruscetti FW, Reitz MS, Kalyanaraman VS, Gallo RC. Isolation of a new type $C$ retrovirus (HTLV) in primary uncultured cells of a patient with Sézary T-cell leukaemia. Nature. 1981;294:268-71.

61. Kalyanaraman V, Sarngadharan M, Robert-Guroff M, Miyoshi I, Golde D, Gallo R. A new subtype of human T-cell leukemia virus (HTLVII) associated with a T-cell variant of hairy cell leukemia. Science. 1982;218:571-3.

62. Gallo RC. History of the discoveries of the first human retroviruses: HTLV-1 and HTLV-2. Oncogene. 2005;24:5926-30.

63. Maloney EM, Biggar RJ, Neel JV, Taylor ME, Hahn BH, Shaw GM, et al. Endemic human T cell lymphotropic virus type II infection among isolated Brazilian Amerindians. J Infect Dis. 1992;166:100-7.

64. Echeverria DPG, Leon-Ponte M, Noya O, Botto C, Gallo D, Bianco N. First description of endemic HTLV-II infection among Venezuelan Amerindians. J Acquir Immune Defic Syndr. 1993;6:1368-72.

65. Mueller N, Okayama A, Stuver S, Tachibana N. Findings from the Miyazaki cohort study. J Acquir Immune Defic Syndr Hum Retrovirol. 1996;13:S2-7.

66. Taylor GP. The epidemiology of HTLV-I in Europe. J Acquir Immune Defic Syndr Hum Retrovirol. 1996;13:S8-14.

67. Feigal E, Murphy E, Vranizan K, Bacchetti P, Chaisson R, Drummond JE, et al. Human T cell lymphotropic virus types I and II in intravenous drug users in San Francisco: risk factors associated with seropositivity. J Infect Dis. 1991;164:36-42.

68. Heneine W, Kaplan J, Gracia F, Lal R, Roberts B, Levine P, et al. HTLV-II endemicity among Guaymi Indians in Panama. N Engl J Med. 1991:324:565.

69. Goubau P, Liu H-F, De Lange GG, Vandamme A-M, Desmyter JAN. HTLVII seroprevalence in Pygmies across Africa since 1970. AIDS Res Hum Retrovir. 1993;9:709-13.

70. Gessain A, de Thé G. What is the situation of human T cell lymphotropic virus type II (HTLV-II) in Africa? Origin and dissemination of genomic subtypes. J Acquir Immune Defic Syndr Hum Retrovirol. 1996;13:S22835. Review. Erratum in: J Acquir Immune Defic Syndr Hum Retrovirol 1996;13:397-8.

71. Gongora-Biachi R, Lal R, Rudolph D, Castro-Sansores C, Gonzalez-Martinez P, Pavia-Ruz N. Low prevalence of HTLV-II in Mayan Indians in the Yucatan Peninsula, Mexico. Arch Med Res. 1997;28:555-8.

72. Fujiyoshi T, Li H-C, Lou H, Yashiki S, Karino S, Zaninovic V, et al. Characteristic distribution of HTLV Type I and HTLV Type II carriers among native ethnic groups in South America. AIDS Res Hum Retrovir. 1999;15:1235-9.

73. Hall WW, Ishak R, Zhu SW, Novoa P, Eiraku N, Takahashi H, et al. Human T lymphotropic virus type II (HTLV-II): epidemiology, molecular properties, and clinical features of infection. J Acquir Immune Defic Syndr Hum Retrovirol. 1996;13:S204-14.

74. Andrada-Serpa MJ, Tosswill J, Schor D, Linhares D, Dobbin J, Pereira MS. Seroepidemiologic survey for antibodies to human retroviruses in human and non-human primates in Brazil. Int J Cancer. 1989;44:389-93.

75. Costa CMDC, Salgueiro MR, Carton H, Vale OCD, Arruda AMD. Tropical spastic paraparesis in Northeastern Brazil. Arq Neuropsiquiatr. 1989:47:134-8.

76. de Oliveira MSP, Famadas LC, Andrada-Serpa MJ, Nucci M, Matutes E Schulz TF, et al. Adult T-cell leukaemia/lymphoma in Brazil and its relation to HTLV-1. Lancet. 1990;336:987-90.

77. Araújo ADQC, Alfonso CR, Schor D, Leite AC, Andrada-Serpa MJ. Clinical and demographic features of HTLV-1 associated myelopathy/tropical spastic paraparesis (HAM/TSP) in Rio de Janeiro, Brazil. Acta Neurol Scand. 1993;88:59-62.

78. Lessa I, Moraes D, Moura L, Melo A. HTLV-1 and myelopathy in Salvador (Northeastern Brazil): a case control study. Arq Neuropsiquiatr. 1993:51:447-51.

79. Moreira ED, Ribeiro TT, Swanson P, Filho CS, Melo A, Brites C, et al. Seroepidemiology of human T-cell lymphotropic virus type I/II in northeastern Brazil. J Acquir Immune Defic Syndr. 1993;6:959-63.

80. Ferreira O, Planelles V, Rosenblatt J. Human T-cell leukemia viruses: epidemiology, biology, and pathogenesis. Blood Rev. 1997;11:91-104.

81. de Carvalho SMF, de Oliveira MSP, Thuler LCS, Rios M, Coelho RCA, Rubim LC, et al. HTLV-I and HTLV-II Infections in hematologic disorder patients, cancer patients, and healthy individuals from Rio de Janeiro, Brazil. J Acquir Immune Defic Syndr Hum Retrovirol. 1997;15:238-42.

82. Ishak R, Ishak MOG, Azevedo VN, Santos DEM, Vallinoto ACR, Crescente $J A$, et al. Detection of HTLV-lla in blood donors in an urban area of the Amazon region of Brazil (Belém, PA). Rev Soc Bras Med Trop. 1998:31:193-7.

83. Ishak R, Cavalcante F, Vallinoto ACR, Azevedo VN, Ishak MOG. HTLV-I associated myelopathy in the northern region of Brazil (Belém-Pará): serological and clinical features of three cases. Rev Soc Bras Med Trop. 2002;35:243-6.

84. Nakauchi CM, Linhares AC, Maruyama K, Kanzaki LI, Macedo JE, Azevedo VN, et al. Prevalence of human T cell leukemia virus-I (HTLV-I) antibody among populations living in the Amazon region of Brazil (preliminary report). Mem Inst Oswaldo Cruz. 1990;85:29-33.

85. Nakauchi CM, Maruyama K, Kanzaki LI, Linhares AC, Azevedo VN, Fukushima T, et al. Prevalence of HTLV-I antibody among two distinct ethnic groups inhabiting the Amazon region of Brazil. Rev Inst Med Trop Sao Paulo. 1992;34:323-8.

86. Black FL, Biggar RJ, Neel JV, Maloney EM, Waters DJ. Endemic transmission of HTLV Type II among Kayapo Indians of Brazil. AIDS Res Hum Retrovir. 1994;10:1165-71.

87. Vallinoto ACR, Pontes GS, Muto NA, Lopes IGL, Machado LFA, Azevedo $\mathrm{VN}$, et al. Identification of human T-cell lymphotropic virus infection in a semi-isolated Afro-Brazilian quilombo located in the Marajó Island (Pará, Brazil). Mem Inst Oswaldo Cruz. 2006;101:103-5.

88. Vallinoto AC, Muto NA, Pontes GS, Machado LF, Azevedo VN, dos Santos $\mathrm{SE}$, et al. Serological and molecular evidence of HTLV-I infection among Japanese immigrants living in the Amazon region of Brazil. Jpn J Infect Dis. 2004;57:156-9.

89. IBGE-Instituto Brasileiro de Geografia e Estatística; 2019. https://ww2. ibge.gov.br/home/. Accessed 15 Sept 2019.

90. Wilson E. Half-earth: our planet's fight for life. New York: Liveright; 2016.

91. Menna-Barreto M, Bender AL, Bonatto SL, Freitas LB, Salzano FM, Tsuneto LT, et al. Human T-cell lymphotropic virus type Il in Guaraní Indians, Southern Brazil. Cad Saude Publica. 2005;21:1947-51.

92. Renner JDP, Laurino JP, Menna-Barreto M, Schmitt VM. Molecular evidence of HTLV-II subtype B among an urban population living in south Brazil. AIDS Res Hum Retrovir. 2006;22:301-6.

93. Ishak R, Machado LFA, Cayres-Vallinoto I, Guimarães Ishak MDO, Vallinoto ACR. Infectious agents as markers of human migration toward the Amazon region of Brazil. Front Microbiol. 2017:8:1663.

94. de Aguiar SA, França SADS, Santana BB, Santos MB, Freitas FB, Ferreira $\mathrm{G}$, et al. Human T-lymphotropic virus $1 \mathrm{aA}$ circulation and risk factors for sexually transmitted infections in an Amazon geographic area with lowest human development index (Marajó Island, Northern Brazil). BMC Infect Dis. 2017;17:758.

95. Marcon CEM, Campos KR, Silva GBD, Schuelter-Trevisol F, Schlindwein $A D$, Trevisol DJ, et al. The first survey of human T-cell lymphotropic viruses (HTLV) in HIV/AIDS patients in Santa Catarina State, Brazil. Rev Inst Med Trop Sao Paulo. 2019;61:e53.

96. Pereira FM, Almeida MDCCD, Santos FLN, Carreiro RP, Regis-Silva CG, Galvão-Castro B, et al. Evidence of new endemic clusters of human T-cell leukemia virus (HTLV) infection in Bahia, Brazil. Front Microbiol. 2019;10:1002

97. Ribeiro ML, Gonçales JP, Morais VMSD, Moura LCRV, Coêlho MRCD. HTLV $1 / 2$ prevalence and risk factors in individuals with HIV/AIDS in Pernambuco, Brazil. Rev Soc Bras Med Trop. 2019;52:e20180244. 
98. Galvao-Castro B, Loures L, Rodriques LG, Sereno A, Junior OCF, Franco $L G$, et al. Distribution of human T-lymphotropic virus type I among blood donors: a nationwide Brazilian study. Transfusion. 1997;37:242-3.

99. Colin DD, Alcântara LCJ, Santos FLN, Uchôa R, Tavares-Neto J. Prevalência da infecção pelo vírus linfotrópico humano de células T e fatores de risco associados à soropositividade em doadores de sangue da cidade de Rio Branco, AC, Brasil (1998-2001). Rev Soc Bras Med Trop. 2003;36:677-983.

100. Catalan-Soares B, Carneiro-Proietti ABDF, Proietti FA. Heterogeneous geographic distribution of human T-cell lymphotropic viruses I and II (HTLV-I/II): serological screening prevalence rates in blood donors from large urban areas in Brazil. Cad Saude Publica. 2005;21:926-31.

101. Mota-Miranda AC, Araújo SP, Dias JP, Colin DD, Kashima S, Covas DT, et al. HTLV-1 infection in blood donors from the Western Brazilian Amazon region: seroprevalence and molecular study of viral isolates. J Med Virol. 2008;80:1966-71.

102. Viana GMDC, Nascimento MDDSB, de Oliveira RAS, dos Santos AC, Galvão CDS, da Silva MACN. Seroprevalence of HTLV-1/2 among blood donors in the state of Maranhão. Brazil. Rev Bras Hematol Hemoter. 2014;36:50-3.

103. Sequeira CG, Tamegão-Lopes BP, Santos EJMD, Ventura AMR, MoraesPinto MI, Succi RCDM. Descriptive study of HTLV infection in a population of pregnant women from the state of Pará, Northern Brazil. Rev Soc Bras Med Trop. 2012;45:453-6.

104. Souza VGD, Martins ML, Carneiro-Proietti ABDF, Januário JN, Ladeira RVP, Silva CMS, et al. High prevalence of HTLV-1 and 2 viruses in pregnant women in São Luis, state of Maranhão, Brazil. Rev Soc Bras Med Trop. 2012;45:159-62.

105. Machado-Filho AC, Sardinha JFJ, Ponte RL, Costa EPD, da Silva SS, Martinez-Espinosa FE. Prevalência de infecção por HIV, HTLV, VHB e de síflis e clamídia em gestantes numa unidade de saúde terciária na Amazônia ocidental Brasileira. Rev Bras Ginecol Obstet. 2010;32:176-83.

106. Guerra AB, Siravenha LQ, Laurentino RV, Feitosa RNM, Azevedo VN, Vallinoto ACR, et al. Seroprevalence of HIV, HTLV, CMV, HBV and rubella virus infections in pregnant adolescents who received care in the city of Belém, Pará, Northern Brazil. BMC Pregnancy Childbirth. 2018;18:169.

107. Maloney EM, Ramirez H, Levin A, Blattner WA. A survey of the human T-cell lymphotropic virus type I (HTLV-I) in South-Western Colombia. Int J Cancer. 1989;44:419-23.

108. Vasquez P, Sanchez G, Volante C, Vera L, Ramirez E, Soto G, et al. Human T-lymphotropic virus type I: new risk for Chilean population. Blood. 1991;78:850-1.

109. Plancoulaine S, Buigues RP, Murphy EL, van Beveren M, Pouliquen JF, Joubert M, et al. Demographic and familial characteristics of HTLV-I infection among an isolated, highly endemic population of African origin in French Guiana. Int J Cancer. 1998;76:331-6.

110. Talarmin A, Vion B, Marty C, Kazanji M, Ureta-Vidal A, Fou GD. First seroepidemiological study and phylogenetic characterization of human T-cell lymphotropic virus type I and II infection among Amerindians in French Guiana. J Gen Virol. 1999;80:3083-8.

111. Vallinoto A, Carvalho F, Santos A, da Silva R, Ribeiro E, Cordeiro K, et al. Occurrence of cross-reactivity to HTLV- $1 / 2$ antigens in patients with malaria from an endemic area of the Brazilian Amazon region. Recent Res Devel Immunol. 2012;82:75-86.
112. Passos LNDM, de Moraes MPE, Tamegão-Lopes B, de Lemos JAR, Machado PRDL, Mira MT, et al. Absence of HTLV- $1 / 2$ infection and dermatological diseases in Manaus, State of Amazonas, Brazil. Rev Soc Bras Med Trop. 2014;47:507-9.

113. Morais MPED, Gato CM, Maciel LA, Lalwani P, Costa CA, Lalwani JDB. Prevalence of human T-lymphotropic virus type 1 and 2 among blood donors in Manaus, Amazonas State, Brazil. Rev Inst Med Trop Sao Paulo. 2017;59:e80.

114. Silva I. Epidemiologia molecular do vírus linfotrópico de de células T humanas, HTLV-1/2 no Estado do Amapá-Brasil (Molecular epidemiology of HTLV-1/2 in the state of Amapa-Brazil). MSc dissertation; 2006.

115. Mendes MFC, Lima JRO, Melo BO, Pinto CMFS, Maia HS, Ferro ATF, et al. Molecular detection of human T cell lymphotropic virus type 1 in pregnant women from Maranhão state, Brazil. Braz J Microbiol. 2020. https:// doi.org/10.1007/s42770-020-00233-0.

116. Santos ELD, Tamegão-Lopes B, Machado LFA, Ishak MOG, Ishak R, Lemos JARD, et al. Caracterização molecular do HTLV-1/2 em doadores de sangue em Belém, Estado do Pará: primeira descrição do subtipo HTLV2b na região Amazônica. Rev Soc Bras Med Trop. 2009;42:271-6.

117. Falcão LFM, Fuzii HT, Libonati RMF, Aarão TLDS, Guimarães AGM, Martins $L C$, et al. Environmental impact and seroepidemiology of HTLV in two communities in the eastern Brazilian amazon. J Med Virol. 2013;85:1585-90.

118. Silva IC, Pinheiro BT, Nobre AFS, Coelho JL, Pereira CCC, Ferreira LDSC, et al. Moderada endemicidade da infecção pelo vírus linfotrópico-T humano na região metropolitana de Belém, Pará, Brasil. Rev Bras Epidemiol. 2018;21:e180018.

119. Laurentino RV, Lopes IGL, Azevedo VN, Machado LFA, Moreira MRC, Lobato $L$, et al. Molecular characterization of human T-cell lymphotropic virus coinfecting human immunodeficiency virus 1 infected patients in the Amazon region of Brazil. Mem Inst Oswaldo Cruz. 2005;100:371-6.

120. de Sousa BA, dos Santos LV, Oliveira TR, Dias AL, da Costa CA, Sousa $\mathrm{RCM}$, et al. Dermatological manifestations in patients with human T-cell lymphotropic virus at a reference service in Amazon. Int J Dermatol. 2019;58:953-60.

121. Falcão LFM, Falcão ASC, Sousa RCM, Vieira WDB, de Oliveira RTM, Normando VMF, et al. CT Chest and pulmonary functional changes in patients with HTLV-associated myelopathy in the Eastern Brazilian Amazon. PLoS ONE. 2017:12:e0186055.

122. Vallinoto ACR, Otake MI, Sousa PVNR, Lopes FT, Sacuena ERP, Queiroz $M A F$, et al. Isolation of the Arawete and Asurini Indians keeps the tribes free from HTLV infection during 36 years of follow-up. Retrovirology. 2019;16:27.

123. Bastian I, Hinuma Y, Doherty RR. HTLV-I among northern territory Aborigines. Med J Aust. 1993;159:12-6.

124. Martin F, Tagaya Y, Gallo R. Time to eradicate HTLV-1: an open letter to WHO. Lancet. 2018;391:1893-4.

\section{Publisher's Note}

Springer Nature remains neutral with regard to jurisdictional claims in published maps and institutional affiliations.

Ready to submit your research? Choose BMC and benefit from:

- fast, convenient online submission

- thorough peer review by experienced researchers in your field

- rapid publication on acceptance

- support for research data, including large and complex data types

- gold Open Access which fosters wider collaboration and increased citations

- maximum visibility for your research: over $100 \mathrm{M}$ website views per year

At BMC, research is always in progress.

Learn more biomedcentral.com/submissions 